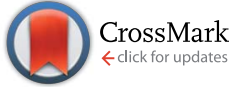

Cite this: J. Mater. Chem. A, 2017, 5, 2251

Received 5th November 2016

Accepted 24th December 2016

DOI: $10.1039 / \mathrm{c} 6 \mathrm{ta0} 0572 \mathrm{k}$

www.rsc.org/MaterialsA

\title{
A sol-gel route to titanium nitride conductive coatings on battery materials and performance of TiN-coated $\mathrm{LiFePO}_{4} \dagger$
}

\begin{abstract}
Min Zhang, Nuria Garcia-Araez, ${ }^{*}$ Andrew L. Hector* and John R. Owen
New approaches to produce nanocrystalline TiN materials with high conductivity and their application as conductive coatings on battery materials have been developed. Sol-gel synthesis routes using tetrakis(dimethylamido)titanium(Iv) and a propylamine or ammonia cross linking agent, followed by thermal treatment under $\mathrm{NH}_{3}$ or $\mathrm{H}_{2}+\mathrm{N}_{2}$, were found to produce TiN powders of small crystallite size $(<10 \mathrm{~nm})$, with good conductivity in selected cases. The most promising synthesis conditions were used to produce even $\mathrm{TiN}$ coatings on $\mathrm{LiFePO}_{4}$ particles, and the resulting materials exhibited significantly improved electrochemical performance relative to uncoated $\mathrm{LiFePO}_{4}$, in terms of higher specific capacity, cycle stability and rate capability. The material with the optimum $10 \mathrm{wt} \% \mathrm{TiN}$ content exhibited a discharge capacity of $159 \mathrm{~mA} \mathrm{~h} \mathrm{~g}$, that is $\sim 93 \%$ of the theoretical capacity, when charge/discharge rates of $0.1 \mathrm{C}$ were applied. The results demonstrate the suitability of this new route to produce TiN coatings, which could also be applied to high voltage materials or for materials to be operated at high temperatures, where corrosion or degradation of other coating materials (e.g. carbon) would be problematic.
\end{abstract}

\section{Introduction}

Metal nitrides have been studied as electrode materials for batteries and supercapacitors in their own right for some years. ${ }^{1}$ However, they have also been combined with other electrode materials to form structured composites with improved conductivity and stability relative to the active electrode material itself. ${ }^{2-5}$ TiN is suitable for these purposes as it possesses good electrical conductivity, low cost, and good chemical and thermal stability. ${ }^{6,7}$ For example, Kim and co-workers reported good electrochemical performance in $\mathrm{Si} / \mathrm{TiN}$ nanocomposites in which the electrochemically inactive TiN acts to maintain the stability of the nanocomposite during cycling as silicon undergoes volumetric change. ${ }^{4} \mathrm{Li}_{4} \mathrm{Ti}_{5} \mathrm{O}_{12}$ suffers from poor electronic conductivity, but DeSisto et al. showed that atomic layer deposition of TiN coatings onto $\mathrm{Li}_{4} \mathrm{Ti}_{5} \mathrm{O}_{12}$ powder improved the electronic conductivity to deliver a higher capacity (162 $\mathrm{mA} \mathrm{h} \mathrm{g}^{-1}$ ) and cycling stability compared with that of uncoated $\mathrm{Li}_{4} \mathrm{Ti}_{5} \mathrm{O}_{12}\left(133 \mathrm{~mA} \mathrm{~h} \mathrm{~g}{ }^{-1}\right) .^{5}$

Many methods have been developed to synthesise metal nitrides, from elemental combination, including at high pressure ${ }^{8}$ to ammonolysis of oxides and other binary compounds, ${ }^{9}$ vapour deposition of films, ${ }^{\mathbf{1 0}}$ solid state metathesis and

Chemistry, University of Southampton, Highfield, Southampton SO17 1BJ, UK. E-mail: N.Garcia-Araez@soton.ac.uk; A.L.Hector@soton.ac.uk

$\uparrow$ Electronic supplementary information (ESI) available. See DOI: 10.1039/c6ta09572k solvothermal reactions, ${ }^{\mathbf{1 1 , 1 2}}$ reactions of molecular precursors and sol-gel processing. ${ }^{13,14}$ Sol-gel methods have been shown to be highly effective, low cost routes to nitride materials and are versatile in the preparation of high surface area materials or porous structures. ${ }^{\mathbf{1 5 , 1 6}}$ Ammonia can be used to cross-link precursor molecules via transamination reactions to produce materials such as nanocrystalline $\mathrm{TiN},{ }^{\mathbf{1 7}, 18}$ but we have shown that to process films ${ }^{13}$ and for controlled morphologies such as polymer sphere templated inverse opals ${ }^{19,20}$ the use of a primary amine as the crosslinking agent can be particularly effective. The advantage for battery material coatings is that the use of a sol-gel route could be a scalable with efficient material usage compared with vapour phase coating methods.

The ordered olivine structured $\mathrm{LiFePO}_{4}$ has been intensively investigated as a cathode material in lithium-ion batteries due to its flat voltage profile, high theoretical capacity of $170 \mathrm{~mA} \mathrm{~h} \mathrm{~g}{ }^{-1}$, safety, low cost and environment benignity. ${ }^{21-24}$ However, the low intrinsic electronic conductivity $\left(\sim 10^{-8}\right.$ to $\left.10^{-10} \mathrm{~S} \mathrm{~cm}^{-1}\right)$ and lithium-ion diffusivity $\left(\sim 10^{-18} \mathrm{~cm}^{2} \mathrm{~s}^{-1}\right)$ of $\mathrm{LiFePO}_{4}$ are major obstacles which originally limited its practical applications. ${ }^{25-27}$ Approaches to ameliorate these drawbacks have included cation doping, ${ }^{28-31}$ particle size reduction, ${ }^{32,33}$ carbon coating ${ }^{34-36}$ and non-carbon second phase modification. ${ }^{37,38}$ Carbon coating has become the standard method to enhance the electronic conductivity of $\mathrm{LiFePO}_{4}$ particles. However, carbon layers have low density $\left(2.2 \mathrm{~g} \mathrm{~cm}^{-3}\right)$ and this may reduce the tap density of $\mathrm{LiFePO}_{4}\left(3.6 \mathrm{~g} \mathrm{~cm}^{-3}\right)$, leading to reduced volumetric energy density of the lithium ion battery electrodes..$^{39,40}$ Other electrode 
materials such as $\mathrm{LiMnPO}_{4}, \mathrm{LiCoPO}_{4}, \mathrm{LiNiPO}_{4}, \mathrm{LiMn}_{2} \mathrm{O}_{4}$ and $\mathrm{Li}_{4} \mathrm{Ti}_{5} \mathrm{O}_{12}$ also suffer from poor electrical conductivity and can benefit from coating to enhance electron transport. ${ }^{41}$

New processes to produce conductive coatings could improve battery performance by providing alternatives to carbon. Whilst carbon-coated $\mathrm{LiFePO}_{4}$ is highly optimised and is in commercial use ${ }^{42,43}$ other materials such as TiN could provide better stability with high voltage materials or in cells that are more stable at elevated temperature. ${ }^{1,44}$ TiN could provide more effective protection from chemical attack by HF produced by electrolyte decomposition and thus suppress the dissolution of $\mathrm{Fe}$ from $\mathrm{LiFePO}_{4}$ in $\mathrm{LiPF}_{6}$ based electrolytes. ${ }^{38,40}$ Since $\mathrm{LiFePO}_{4}$ is well understood but dependent on conductive coatings it provides an effective test bed for new coating materials. Hence in this work we have investigated possible sol-gel approaches to TiN coatings on battery materials, the feasibility of transferring these methods to $\mathrm{LiFePO}_{4}$ particles and the electrochemical performance of TiN coated $\mathrm{LiFePO}_{4}$.

\section{Experimental}

\section{Synthesis}

Titanium amides and the sol-gel intermediates were handled under nitrogen using glove box or Schlenk line methods. Two main methods were used to produce TiN based on literature routes using ammonia ${ }^{18}$ or propylamine ${ }^{20}$ cross-linking agents:

(1) $\mathrm{Ti}\left(\mathrm{NMe}_{2}\right)_{4}\left(2.65 \mathrm{~cm}^{3}, 11.2 \mathrm{mmol}\right.$, Epichem) was dissolved in dry THF $\left(20 \mathrm{~cm}^{3}\right.$, distilled from sodium/benzophenone). Liquid $\mathrm{NH}_{3}\left(\sim 20 \mathrm{~cm}^{3}\right)$ was distilled from a sodium/ammonia solution into the stirred amide solution cooled to $-78{ }^{\circ} \mathrm{C}$. A bright yellow precipitate appeared on first exposure of the solution to ammonia, which turned brown and then black as the ammonia was allowed to evaporate and the temperature approached ambient.

(2) $\mathrm{Ti}\left(\mathrm{NMe}_{2}\right)_{4}\left(2.65 \mathrm{~cm}^{3}, 11.2 \mathrm{mmol}\right)$ was dissolved in dry THF $\left(7.5 \mathrm{~cm}^{3}\right) .{ }^{n} \mathrm{PrNH}_{2}\left(1.84 \mathrm{~cm}^{3}, 22.4 \mathrm{mmol}\right.$, distilled from $\left.\mathrm{BaO}\right)$ was slowly added. The solution gradually changed colour from yellow to red-orange.

Both sol types were stirred at room temperature overnight and then pumped off to form viscous gels. These were then heated under a flow of $\mathrm{NH}_{3}$ (dried with a column of molecular sieves) or $5 \% \mathrm{H}_{2}$ in $\mathrm{N}_{2}$ at $3{ }^{\circ} \mathrm{C} \min ^{-1}$ to $650{ }^{\circ} \mathrm{C}$ and maintained for $6 \mathrm{~h}$ before cooling. The products were black powders, or a metallic red monolith from the propylamine crosslinked gel heated in ammonia. Both types were ground in a pestle and mortar before further characterisation.

$\mathrm{LiFePO}_{4}$ was prepared by a literature hydrothermal method..$^{45} \mathrm{LiOH} \cdot \mathrm{H}_{2} \mathrm{O}(6.29 \mathrm{~g}, 0.15 \mathrm{~mol}$, 98\% purity, Fisher Scientific) was dissolved in deionised water $\left(45 \mathrm{~cm}^{3}\right)$, and $\mathrm{H}_{3} \mathrm{PO}_{4}$ aqueous solution $\left(3.77 \mathrm{~cm}^{3}, 0.05 \mathrm{~mol}, 85.3 \mathrm{wt} \%\right.$ assay, Fisher Scientific) was added. $\mathrm{FeSO}_{4} \cdot 7 \mathrm{H}_{2} \mathrm{O}(13.90 \mathrm{~g}, 0.05 \mathrm{~mol},>99 \%$ purity, ACROS Organics) was dissolved in water $\left(45 \mathrm{~cm}^{3}\right)$ and added slowly to the LiOH solution with constant stirring, during which time a light green suspension formed. The precursor solution was heated in a Parr 4748 Teflon-lined autoclave $\left(125 \mathrm{~cm}^{3}\right)$ at $180{ }^{\circ} \mathrm{C}$ for $6 \mathrm{~h}$. The precipitate was then washed with deionized water and ethanol, and dried at $80{ }^{\circ} \mathrm{C}$ for $5 \mathrm{~h}$ under vacuum. The resulting material, which we have designated LFP(HT), was heated at $3{ }^{\circ} \mathrm{C} \mathrm{min}^{-1}$ to $650^{\circ} \mathrm{C}$ and maintained for $6 \mathrm{~h}$ under ammonia or $5 \% \mathrm{H}_{2} / \mathrm{N}_{2}$ to crystallise $\mathrm{LiFePO}_{4}$.

TiN modified $\mathrm{LiFePO}_{4}$ powders were prepared using a variation of the propylamine cross-linking sol-gel method described above, with the sol prepared from $0.21 \mathrm{~cm}^{3} \mathrm{Ti}\left(\mathrm{NMe}_{2}\right)_{4}, 7.5 \mathrm{~cm}^{3}$ THF and $0.15 \mathrm{~cm}^{3}$ propylamine. $0.5 \mathrm{~g}$ dry LFP(HT) or fired $\mathrm{LiFePO}_{4}$ was added just before the propylamine. The suspension was stirred at room temperature for $\sim 16 \mathrm{~h}$ and dried in vacuo to form a sticky powder. This was heated under ammonia or $5 \% \mathrm{H}_{2} / \mathrm{N}_{2}$ as described above for TiN samples.

\section{Characterisation and electrochemistry}

Powder X-ray diffraction used a Bruker D2 Phaser with $\mathrm{CuK}_{\alpha}$ radiation, and data was fitted using the GSAS package. ${ }^{46}$ Scanning electron microscopy was carried out with a Philips XL-30 ESEM $(20 \mathrm{kV})$ and energy-dispersive X-ray (EDX) analysis with a Thermofisher Ultradry detector with Noran System 7 processing. Transmission electron microscopy used a FEI Tecnai T12 (120 kV). Combustion (C, H, N) analysis was outsourced to Medac Ltd. Electrochemical testing used a Biologics VMP-2 multichannel potentiostat.

Conductivity measurements were carried out on TiN pellets made by manually mixing $0.2 \mathrm{~g}$ TiN powder with PTFE $(0.02 \mathrm{~g})$ in a pestle and mortar. The resulting solid lump was hand rolled (Durston Rolling Mill) into a film and cut into disks with diameter of $10 \mathrm{~mm}$, and then the pellet was assembled into a Swagelok cell without any electrolyte. Cyclic voltammograms (CV) were collected at $20 \mathrm{mV} \mathrm{s}^{-1}$ over the range of -0.3 to $+0.3 \mathrm{~V}(-0.1$ to $+0.1 \mathrm{~V}$ for more conductive samples) at room temperature.

Electrodes for use in lithium half cells were prepared by mixing the $\mathrm{LiFePO}_{4}$ or TiN coated $\mathrm{LiFePO}_{4}$ powder (80 wt\%) with acetylene black (10 wt\%) and poly(vinylidene fluoride) (10 wt\%) dissolved in $N$-methyl-pyrrolidone. The slurry was cast onto Al foil $(125 \mu \mathrm{m}$ thick, temper annealed, $99.0 \%$ purity, Advent Research Materials) and dried at $120^{\circ} \mathrm{C}$ in vacuo for $12 \mathrm{~h}$. The foil was cut into circular discs with a diameter of $1 \mathrm{~cm}$ and pressed at 10 tons to obtain the cathode with a typical mass of $\sim 0.037 \mathrm{~g}$. Swagelok cells were assembled in an argon-filled glove box with lithium foil (Rockwood Lithium $\mathrm{GmbH}$ ) anodes and glass microfiber filter (Whatman, GF/F grade) separators soaked in 8 drops of $1 \mathrm{~mol} \mathrm{dm}^{-3} \mathrm{LiPF}_{6}$ in ethylene carbonate/dimethyl carbonate (EC:DMC = 1:1 in volume) electrolyte (BASF, LP30). Galvanostatic testing was carried out (at least in duplicate) at $25{ }^{\circ} \mathrm{C}$ at various rates of charge/discharge (e.g. $0.1 \mathrm{C}$ is a current calculated for $0.1 \times$ the theoretical capacity per hour) within the voltage range of $2.5-4.5 \mathrm{~V}\left(\nu s . \mathrm{Li}^{+} / \mathrm{Li}\right)$.

\section{Results and discussion}

Titanium nitride was initially made by two different sol-gel routes, then the route that led to the more conductive nanocrystalline material was used to coat $\mathrm{LiFePO}_{4}$ with a variety of processing conditions and thicknesses. 


\section{Synthesis, microstructure and electrochemistry of TiN}

The sol-gel routes to TiN employed $\mathrm{Ti}\left(\mathrm{NMe}_{2}\right)_{4}$ with either propylamine or ammonia as the cross-linking agent (Scheme 1). We have previously used these routes to produce TiN in nanocrystalline form and shown that it can be produced at a range of temperatures, ${ }^{\mathbf{1 3 , 1 8 , 4 7}}$ but here we have fired samples under conditions relevant to the production of coated $\mathrm{LiFePO}_{4}$. The crystallisation temperature affects purity, crystallite/particle size distribution and discharge capacity of $\mathrm{LiFePO}_{4},{ }^{51-53}$ but most successful studies produce $\mathrm{LiFePO}_{4}$ samples at $600-700{ }^{\circ} \mathrm{C} . .^{39,54,55}$ In this study samples were fired at $650{ }^{\circ} \mathrm{C}$. Heating in ammonia minimises the amount of carbon incorporated into the samples but may result in residual surface amide groups that could reduce the stability of the material and the conductivity. These may be removed by cooling in argon. $\mathrm{LiFePO}_{4}$ is typically made in a dilute hydrogen stream, ${ }^{\mathbf{4 8 , 4 9}}$ but when used to fire TiN this is likely to result in more ligand pyrolysis and carbon incorporation either as carbonitride or a separate phase. All three approaches were used. The samples were characterized by X-ray diffraction, electrochemical measurements of the effective conductivity, TEM and elemental analysis, and the main results are summarized in Table 1.

All the X-ray diffraction peaks of the resulting TiN samples (Fig. 1) can be indexed to the standard cubic TiN structure (JCPDS card no. 65-0414). Table 1 shows the crystallographic data of TiN series samples. The Rietveld fits (Fig. S1†) to this XRD data resulted in similar lattice parameters (Table 1) to those in the literature for TiN. ${ }^{50}$ The peak broadening in the Rietveld fit indicated average TiN crystallite sizes of 5-10 nm. These were consistent with TEM images (Fig. S2 $\dagger$ ), which showed aggregates of particles within the same size range. These small sizes are important for coating of battery materials and are probably necessary to evenly coat particles that may only be tens or hundreds of nm in size.

The propylamine-derived sample heated in $5 \% \quad \mathrm{H}_{2} / \mathrm{N}_{2}$ ( $\mathrm{TiN}-{ }^{n} \mathrm{PrNH}_{2}\left(\mathrm{H}_{2} \mathrm{~N}_{2}\right)$ ) contained more carbon $(20.7 \mathrm{wt} \%$ ) than those heated in ammonia. This sample had the smallest crystallite size of 5.02(16) nm. The TEM image in Fig. S2† shows an amorphous layer on its surface which is likely to be carbon, but since no carbon diffraction peaks are observed the carbon must be amorphous. All samples heated in $\mathrm{NH}_{3}$ have $\mathrm{C}$ contents of $2.5 \%$ or less. Incorporation of carbon into the rocksalt lattice to make $\mathrm{Ti}(\mathrm{C}, \mathrm{N})$ compositions occurs readily and where small amounts of carbon are in the sample it is likely to be in the lattice. The carbonitrides are also good conductors and this is unlikely to reduce functionality. TiN $-{ }^{n} \operatorname{PrNH}_{2}\left(\mathrm{H}_{2} \mathrm{~N}_{2}\right)$ and all the ammonia crosslinked samples also had high hydrogen contents. This suggests the presence of alkyl or amide/imide groups, which may reduce the conductivity of the materials.

In order to evaluate the conductivity that TiN samples would produce in a composite electrode, TiN samples were mixed with PTFE binder and calendared to produce self-standing TiN disks, which were dry contacted with two cylindrical pistons in a Swagelok cell and cyclic voltammograms measured to observe the current-voltage profile. The conductivity of TiN was calculated based on $C=S A / l$, where $C\left(\mathrm{~mA} \mathrm{~V}^{-1}\right)$ is the conductance of the pellet, $S\left(\mathrm{~S} \mathrm{~m}^{-1}\right)$ is the conductivity of the $\mathrm{TiN}, A\left(\mathrm{~mm}^{2}\right)$ is the cross-sectional area of the TiN pellet, and $l(\mathrm{~mm})$ is the thickness of the TiN pellet. The measured conductivities in Table 1 were calculated from the current-potential plots shown in Fig. 2 and S3. $\dagger$ As expected the propylamine crosslinked samples heated in ammonia, where hydrogen contents were low, had significantly higher conductivities. Replacing the gas flow with Ar after heating improved the conductivity a little, but it was a small effect. High conductivities were only achieved with the propylamine crosslinker so coating of $\mathrm{LiFePO}_{4}$ was attempted using this system.

\section{Effect of heating environment on $\mathrm{LiFePO}_{4}$}

TiN from the chosen propylamine crosslinking route was found to be more conductive when fired in ammonia (Table 1). Uncoated $\mathrm{LiFePO}_{4}$ was produced with firing in ammonia or in the more typical dilute hydrogen, ${ }^{\mathbf{4 8 , 4 9}}$ to check whether heating in ammonia caused a deterioration in the $\mathrm{LiFePO}_{4}$ properties. Scheme 2 shows the sample labels used for different sample types.

All the X-ray diffraction peaks of $\mathrm{LiFePO}_{4}$ produced by heating the hydrothermal product (LFP(HT)) at $650{ }^{\circ} \mathrm{C}$ under $5 \% \mathrm{H}_{2} / \mathrm{N}_{2}$ (Fig. 3) were consistent with the standard olivine $\mathrm{LiFePO}_{4}$ structure (JCPDS card no. 40-1499, space group Pnma) as expected. The lattice parameters obtained from Rietveld fitting (Fig. S4 and Table S1 $\dagger$ ) are very close to the literature value. ${ }^{56} \mathrm{LFP}(\mathrm{HT})$ was also heated at temperatures between 450 and $750{ }^{\circ} \mathrm{C}$ under $\mathrm{NH}_{3}$ to investigate any effects on the microstructure of $\mathrm{LiFePO}_{4}$. The XRD patterns of these samples are shown in Fig. 3 and S5. $\dagger$ Very little change is observed, with no secondary phases and very little variation in the lattice parameters from the Rietveld fits (Table $\mathrm{S} 1 \dagger$ ). Hence heating in $\mathrm{NH}_{3}$ at temperatures up to $750{ }^{\circ} \mathrm{C}$ does not affect the crystal structure of $\mathrm{LiFePO}_{4}$.

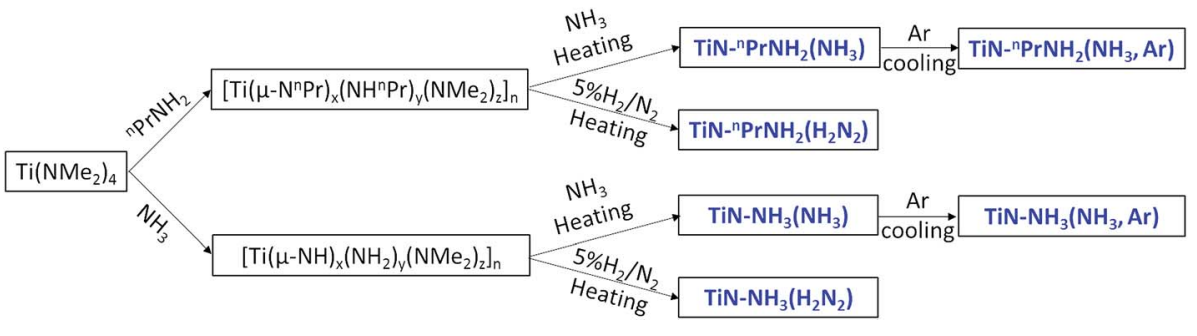

Scheme $1{ }^{n} \mathrm{PrNH}_{2}$ - or $\mathrm{NH}_{3}$-based sol-gel routes to TiN and sample labels. 
Table 1 Lattice parameters and crystallite sizes obtained from the Rietveld fits to the XRD patterns, combustion analysis (C, H, N) results and conductivities of the TiN samples (labels explained in Scheme 1)

\begin{tabular}{|c|c|c|c|c|c|c|}
\hline Sample & $a / \AA$ & Crystallite size/nm & $\% \mathrm{C}$ & $\% \mathrm{H}$ & $\% \mathrm{~N}$ & Conductivity/S $\mathrm{m}^{-1}$ \\
\hline $\mathrm{TiN}-{ }^{n} \operatorname{PrNH}_{2}\left(\mathrm{NH}_{3}\right)$ & $4.2349(2)$ & $9.57(6)$ & 1.55 & $<0.10$ & 21.26 & 5.5 \\
\hline $\mathrm{TiN}-{ }^{n} \mathrm{PrNH}_{2}\left(\mathrm{NH}_{3}, \mathrm{Ar}\right)$ & $4.2336(2)$ & $9.89(6)$ & 1.29 & $<0.10$ & 21.31 & 7.9 \\
\hline $\mathrm{TiN}-\mathrm{NH}_{3}\left(\mathrm{NH}_{3}\right)$ & $4.2237(2)$ & $8.47(7)$ & 2.53 & 1.49 & 16.43 & $7.7 \times 10^{-3}$ \\
\hline $\mathrm{TiN}-\mathrm{NH}_{3}\left(\mathrm{NH}_{3}, \mathrm{Ar}\right)$ & $4.2220(3)$ & $7.00(7)$ & 0.55 & 1.25 & 18.65 & $1.3 \times 10^{-1}$ \\
\hline TiN-NH ${ }_{3}\left(\mathrm{H}_{2} \mathrm{~N}_{2}\right)$ & $4.2350(11)$ & $7.61(23)$ & 5.36 & 1.25 & 15.65 & $1.7 \times 10^{-2}$ \\
\hline
\end{tabular}

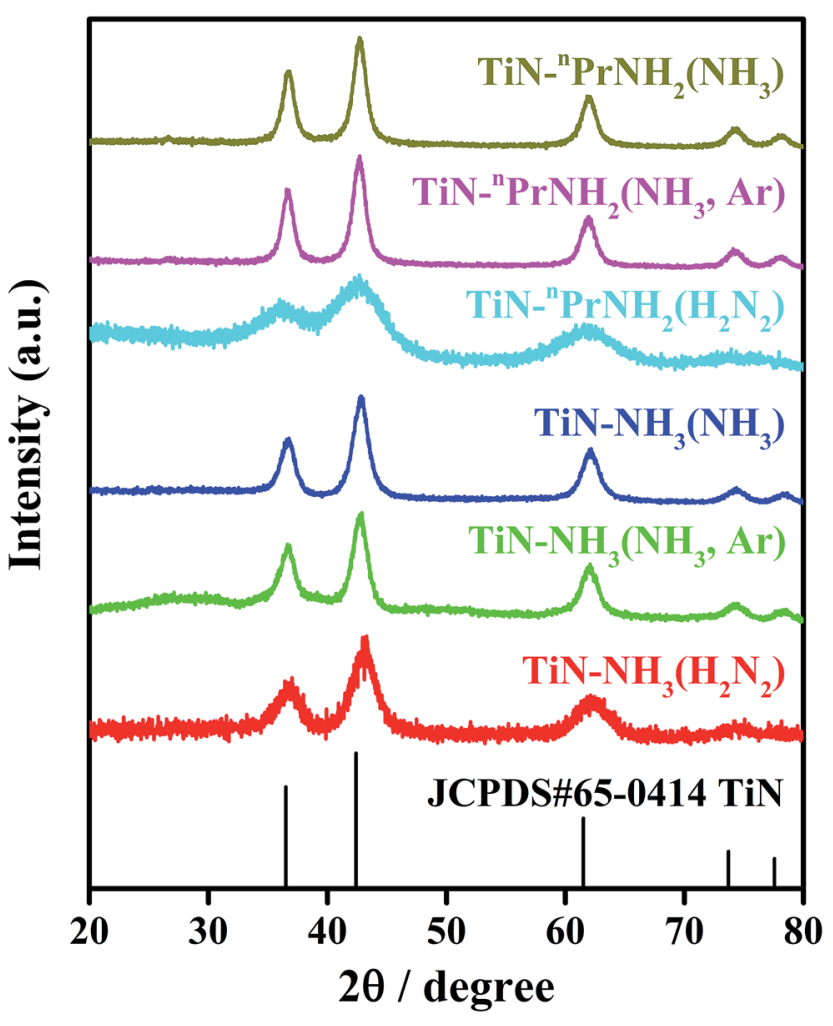

Fig. 1 XRD patterns of TiN series samples prepared using the propylamine or $\mathrm{NH}_{3}$ based sol-gel routes and heated to $650{ }^{\circ} \mathrm{C}$ under different atmospheres (labels explained in Scheme 1). The black stick pattern denotes the literature TiN reflection positions and intensities.

The electrochemical performance of uncoated $\mathrm{LiFePO}_{4}$ is expected to be poor because of its low electronic conductivity. ${ }^{25,57}$ Cui et al. ${ }^{58}$ reported similar $\mathrm{LiFePO}_{4}$ samples to have a capacity of $96 \mathrm{~mA} \mathrm{~h} \mathrm{~g}{ }^{-1}$ at $0.1 \mathrm{C}$ and that this capacity drops quickly with cycling, especially at high rates. Fig. 3 shows the initial charge/discharge curves at $0.1 \mathrm{C}$ and cycle stability of the samples produced at $650{ }^{\circ} \mathrm{C}$. In addition to the expected plateau at $\sim 3.5 \mathrm{~V}$ an additional plateau at $\sim 4 \mathrm{~V}$ was observed in the initial charge curve of the material produced in $5 \% \mathrm{H}_{2} / \mathrm{N}_{2}$. The amount of charge associated with the feature faded over subsequent cycles and may be due to the poor conductivity of the electrode or an initial incomplete dispersion of the electrolyte into the electrode. ${ }^{59,60}$ The initial discharge capacities of $\operatorname{LFP}\left(\mathrm{H}_{2} \mathrm{~N}_{2}\right)$ and $\operatorname{LFP}\left(\mathrm{NH}_{3}\right)$ were 108.3 and $93.1 \mathrm{~mA} \mathrm{~h} \mathrm{~g}{ }^{-1}$, respectively, suggesting that ammonia heating results in

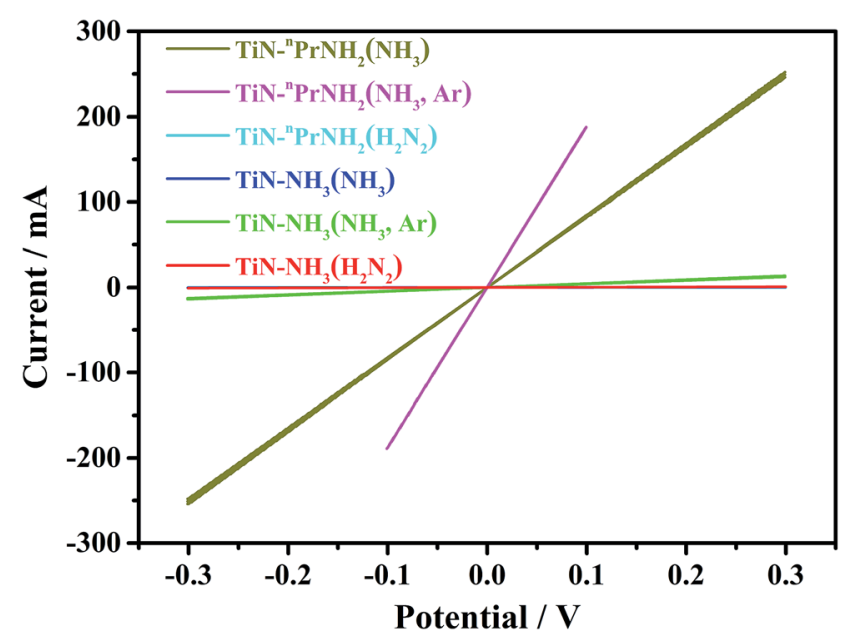

Fig. 2 Current-potential plots (3 cycles each) for dry TiN samples at scanning rate of $20 \mathrm{mV} \mathrm{s}^{-1}$, showing the ohmic behaviour of the samples (labels explained in Scheme 1). Note that the cyan and blue lines are coincident with the red line.

a poorer material. However, the capacity of $\mathrm{LFP}\left(\mathrm{NH}_{3}\right)$ increased slightly to $96.3 \mathrm{~mA} \mathrm{~h} \mathrm{~g}^{-1}$ over 20 cycles, whereas the capacity of $\operatorname{LFP}\left(\mathrm{H}_{2} \mathrm{~N}_{2}\right)$ faded to $80.8 \mathrm{~mA} \mathrm{~h} \mathrm{~g}^{-1}$ over the same number of cycles. Overall this suggested that ammonia is a valid environment for the crystallisation of $\mathrm{LiFePO}_{4}$, but since the results were somewhat similar both heating environments were carried forward to the TiN-coated $\mathrm{LiFePO}_{4}$ samples.

\section{Synthesis, microstructure and electrochemistry of TiN-coated $\mathrm{LiFePO}_{4}$}

Two forms of $\mathrm{LiFePO}_{4}$ were selected for coating, the uncrystallised material directly after the hydrothermal synthesis, giving the possibility of just one heating step, and the material already crystallised under $5 \% \mathrm{H}_{2} / \mathrm{N}_{2}$ (Scheme 2). These were coated using a propylamine-crosslinked sol and the solvent was removed in vacuo. The resulting samples were then fired at 650 ${ }^{\circ} \mathrm{C}$ for $6 \mathrm{~h}$ under $5 \% \mathrm{H}_{2} / \mathrm{N}_{2}$ or ammonia, leading to black solids.

The diffraction patterns of all of the $\mathrm{LiFePO}_{4}$ samples coated with $10 \% \mathrm{TiN}$ (based on amount of $\mathrm{Ti}\left(\mathrm{NMe}_{2}\right)_{4}$ used in preparing the coating sol) were dominated by reflections due to $\mathrm{LiFePO}_{4}$ (Fig. S5 $\dagger$ ). Rietveld fits to these data (Fig. 4 and S6†) yielded typical $\mathrm{LiFePO}_{4}$ lattice parameters (Table $\mathrm{S} 2 \dagger$ ), suggesting that the TiN coating process did not cause any chemical change 


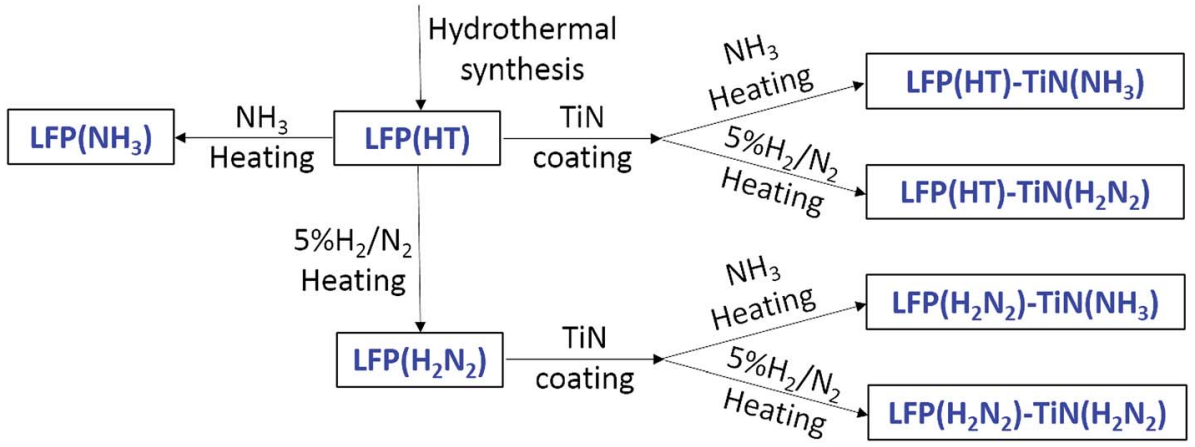

Scheme 2 Preparation conditions and sample labels for TiN-coated $\mathrm{LiFePO}_{4}$ materials.

to the $\mathrm{LiFePO}_{4}$. The average $\mathrm{LiFePO}_{4}$ crystallite sizes were 123-175 nm. Broad reflections matching the expected peak positions for TiN could be observed by close inspection of the difference plots in Rietveld fits where only the $\mathrm{LiFePO}_{4}$ intensity was modelled (Fig. 4b, red line). However, these were only distinct enough to fit in the case of the sample produced from pre-fired $\mathrm{LiFePO}_{4}$ and then fired under ammonia after coating (Fig. 4). The two phase fit (including $\mathrm{LiFePO}_{4}$ and TiN) resulted in a flatter difference line and an improvement in the fit statistics, with $R_{\mathrm{wp}}$ reducing from $0.79 \%$ to $0.72 \%$ (Fig. $4 \mathrm{~b}$, blue line). The refined TiN lattice parameter was 4.217(5) $\AA$, close to that of the TiN samples (Table 1). The TiN crystallite size was refined as $2.6(1) \mathrm{nm}$, significantly smaller than in the bulk TiN samples and potentially useful for producing an even coating on the small $\mathrm{LiFePO}_{4}$ particles. The refined TiN phase fraction was $9.7(6) \%$, close to the $10 \%$ TiN content expected from the $\mathrm{Ti}\left(\mathrm{NMe}_{2}\right)_{4}$ content of the sol.

The electrochemical performance of TiN-coated $\mathrm{LiFePO}_{4}$ samples was assessed by galvanostatic cycling of Li half cells. The initial cycle charge/discharge curves and the variations in
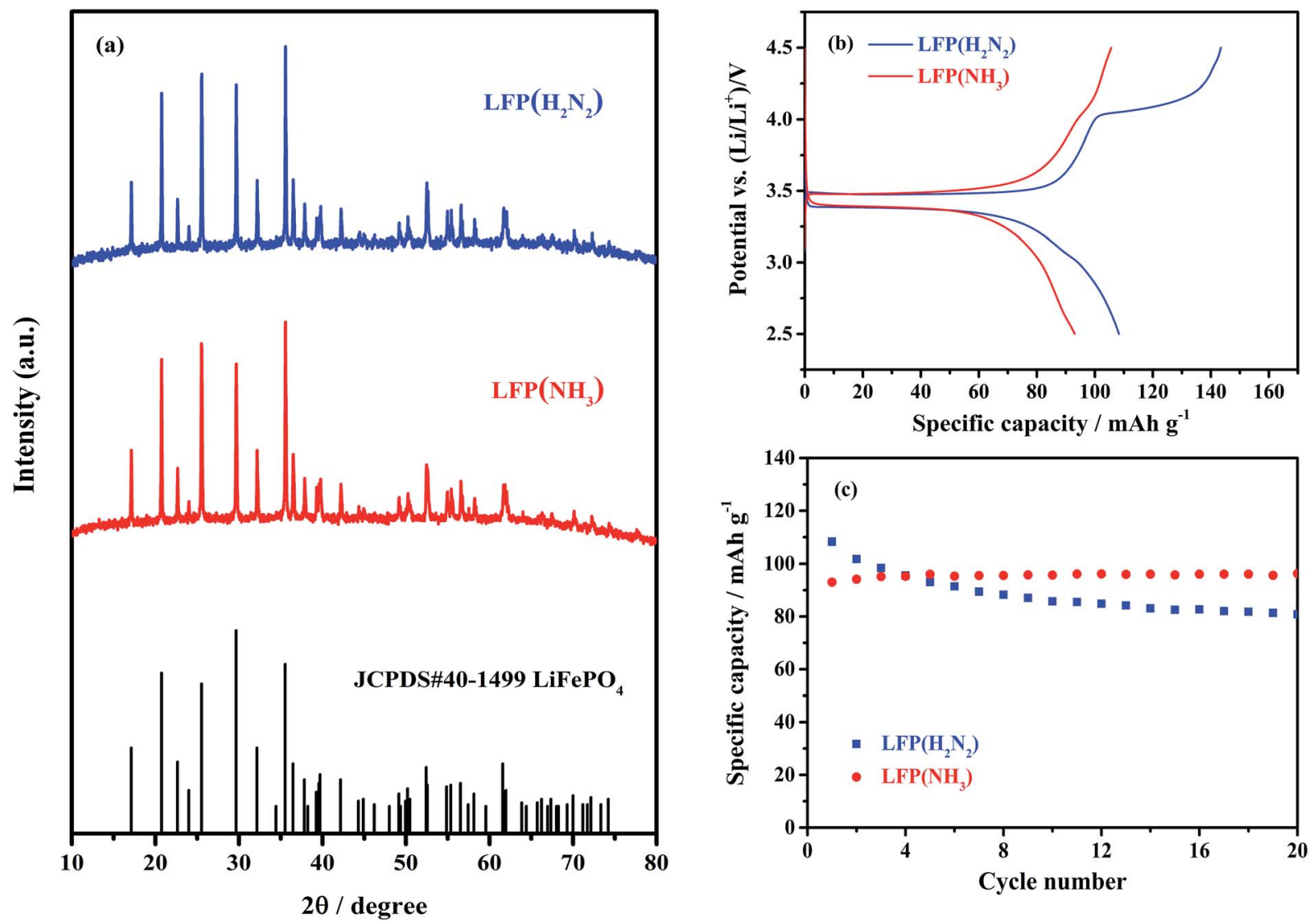

Fig. 3 (a) XRD patterns of $\mathrm{LiFePO}_{4}$ samples heated under $5 \% \mathrm{H}_{2} / \mathrm{N}_{2}$ and $\mathrm{NH}_{3}$, respectively, at $650{ }^{\circ} \mathrm{C}$ (labels explained in Scheme 2). The black stick pattern denotes the literature positions and intensities of $\mathrm{LiFePO}_{4}$ reflections. (b) The initial cycle voltage profile vs. specific capacity and (c) specific capacity vs. cycle number of the same materials in Li half cells, cycled between 2.5 and $4.5 \mathrm{~V}$ for 20 cycles at a current rate of $0.1 \mathrm{C}$. 

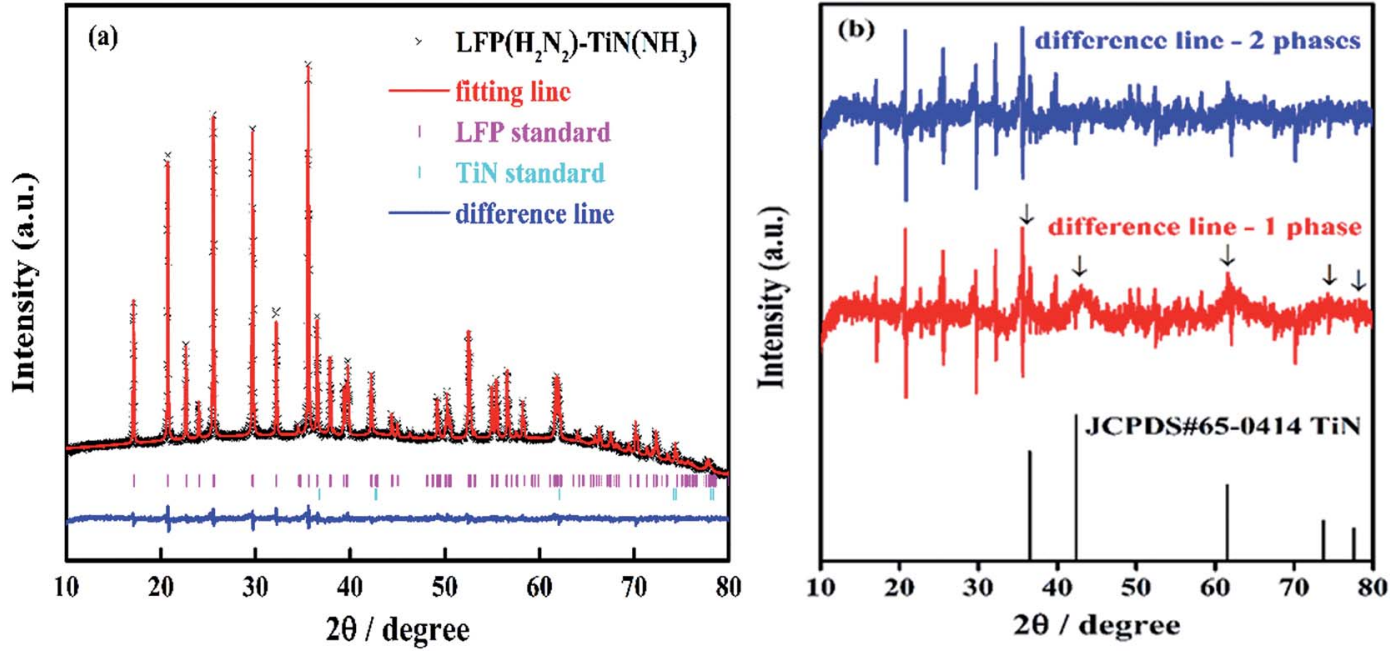

Fig. 4 (a) Rietveld fit $\left(R_{\mathrm{wp}}=0.72 \%\right.$ and $R_{\mathrm{p}}=0.53 \%$ ) to the XRD pattern of $\mathrm{LFP}\left(\mathrm{H}_{2} \mathrm{~N}_{2}\right)-\mathrm{TiN}\left(\mathrm{NH}_{3}\right)$ (sample labels explained in Scheme $2,10 \%$ TiN). The data points and Rietveld fit are overlaid in black crosses and a red line, respectively. The difference plot is shown in blue. The pink and cyan tick marks represent the allowed reflection positions for $\mathrm{LiFePO}_{4}$ with space group Pnma and for TiN with space group $\mathrm{Fm} \overline{3} \mathrm{~m}$, respectively. (b) The difference lines in the 2-phase $\left(\mathrm{LiFePO}_{4}\right.$ and $\left.\mathrm{TiN}\right)$ and 1-phase $\left(\mathrm{LiFePO}_{4}\right)$ Rietveld fits to the same XRD pattern.

discharge capacity over the first 20 cycles are shown in Fig. 5 . $\operatorname{LFP}(\mathrm{HT})-\operatorname{TiN}\left(\mathrm{H}_{2} \mathrm{~N}_{2}\right)$ and $\operatorname{LFP}\left(\mathrm{H}_{2} \mathrm{~N}_{2}\right)-\mathrm{TiN}\left(\mathrm{NH}_{3}\right)$ had the largest initial discharge capacities of 145 and $150 \mathrm{~mA} \mathrm{~h} \mathrm{~g}^{-1}$, respectively. The TiN sample produced with ${ }^{n} \mathrm{PrNH}_{2}$ and fired in $5 \%$ $\mathrm{H}_{2} / \mathrm{N}_{2}$ contained $20.7 \mathrm{wt} \%$ carbon and the TiN-coated $\mathrm{LiFePO}_{4}$ samples produced under these conditions can be expected to contain some carbon, which may play the role of a conductive additive. The capacity of $\operatorname{LFP}(\mathrm{HT})-\mathrm{TiN}\left(\mathrm{H}_{2} \mathrm{~N}_{2}\right)$ drops to $133 \mathrm{~mA} \mathrm{~h} \mathrm{~g}{ }^{-1}$ after 20 cycles whereas $\operatorname{LFP}\left(\mathrm{H}_{2} \mathrm{~N}_{2}\right)-\mathrm{TiN}\left(\mathrm{NH}_{3}\right)$ retains $145 \mathrm{~mA} \mathrm{~h} \mathrm{~g}^{-1}$ after 20 cycles. This material performed significantly better than the uncoated $\mathrm{LiFePO}_{4}$, suggesting that the TiN is providing the required improvement in the electronic conductivity of the composite powders.

TEM images of $\operatorname{LFP}\left(\mathrm{H}_{2} \mathrm{~N}_{2}\right)-\mathrm{TiN}\left(\mathrm{NH}_{3}\right)$ (Fig. 6) showed LiFePO particles with TiN nanoparticles distributed across the $\mathrm{LiFePO}_{4}$ surface. Where particles were aggregated the TiN particles acted to separate the $\mathrm{LiFePO}_{4}$ particles. The presence of the TiN on the surface provides a conducting network between the particles and this is also reflected in the electrochemical performance discussed above. Coatings are also important to prevent $\mathrm{Fe}^{2+}$ dissolution from $\mathrm{LiFePO}_{4}$, which limits degradation of the charge/discharge performance. ${ }^{38,40}$ Fig. S7† shows the EDS analysis of $\operatorname{LFP}\left(\mathrm{H}_{2} \mathrm{~N}_{2}\right)-\operatorname{TiN}\left(\mathrm{NH}_{3}\right)$, which confirms the presence of $\mathrm{Ti}$ on the $\mathrm{LiFePO}_{4}$, with a $9.5 \mathrm{wt} \%$ TiN content calculated from the $\mathrm{Ti}: \mathrm{Fe}$ ratio. The combustion analysis of this sample showed it to contain $0.55 \% \mathrm{C},<0.10 \% \mathrm{H}$ and $1.78 \%$ N. A sample containing $10 \%$ TiN would contain $2.26 \% \mathrm{~N}$, a value that is close to the carbon and nitrogen content of this sample combined. Hence the coating is probably a carbonitride of approximate composition $\mathrm{TiC}_{0.25} \mathrm{~N}_{0.75}$.

The $10 \%$ TiN compositions described above were initially studied based on producing a coating of similar thickness to a typical carbon coating, which is typically $5-8 \% \mathrm{C}$, a lower content by mass because carbon is less dense. ${ }^{42,61}$ For $\operatorname{LFP}\left(\mathrm{H}_{2} \mathrm{~N}_{2}\right)-\mathrm{TiN}\left(\mathrm{NH}_{3}\right)$, which was the highest capacity material at $10 \%$ TiN, variations in the TiN content of the composites
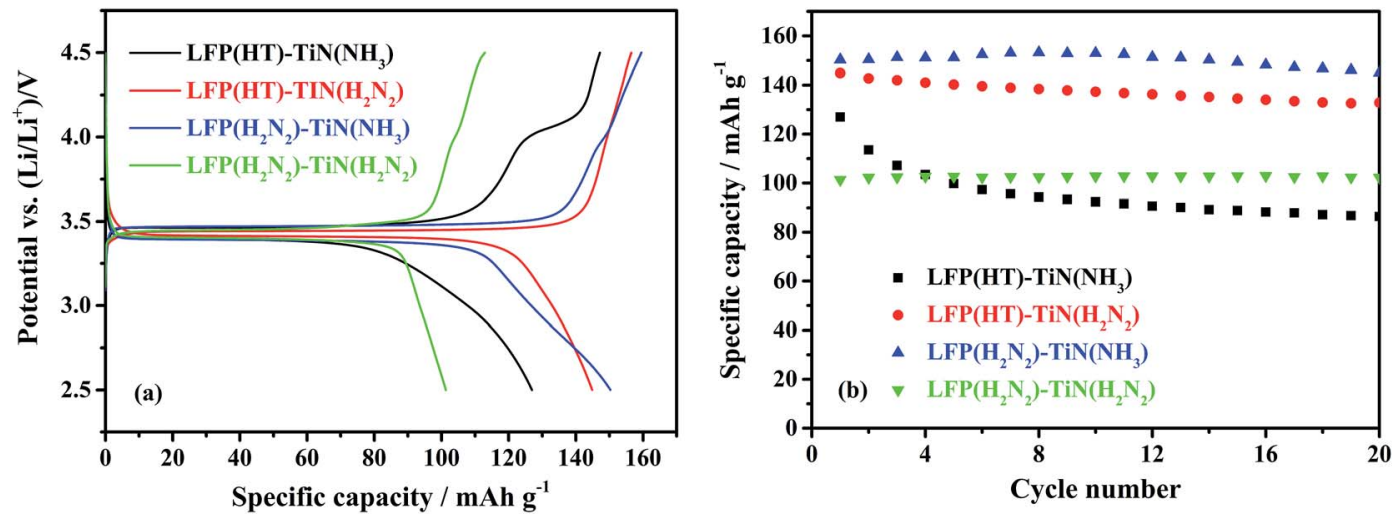

Fig. 5 The initial cycle of voltage profile against specific capacity (a) and specific capacity versus cycle number (b) of TiN-coated LiFePO ${ }_{4} / \mathrm{Li}$ half cells, under galvanostatic cycling between 2.5 and $4.5 \mathrm{~V}$ at $0.1 \mathrm{C}$ (sample labels explained in Scheme 2, 10\% TiN). 


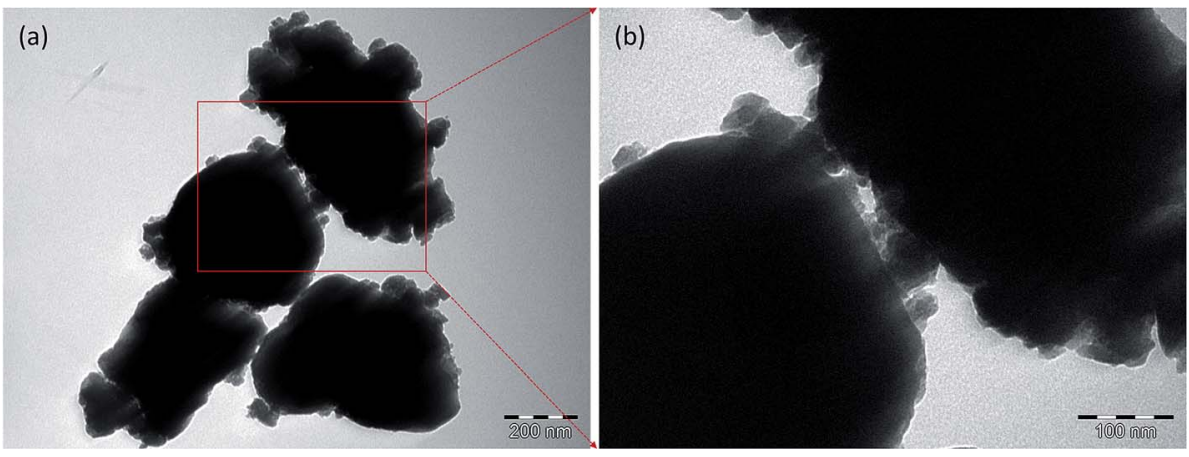

Fig. 6 TEM images of $\operatorname{LFP}\left(\mathrm{H}_{2} \mathrm{~N}_{2}\right)-\mathrm{TiN}\left(\mathrm{NH}_{3}\right)$ ((a), scale bar $\left.=200 \mathrm{~nm}, 10 \% \mathrm{TiN}\right)$ and enlarged view of the region marked by the red box ((b), scale bar $=100 \mathrm{~nm}$ ). Sample labels are explained in Scheme 2 .

were examined. The initial charge/discharge curves of materials containing $0 \%, 2.5 \%, 5 \%, 7.5 \%, 10 \%$ and $12.5 \%$ TiN are shown in Fig. 7, with initial discharge capacities of 108, 112, 129, 132, 150 and $142 \mathrm{~mA} \mathrm{~h} \mathrm{~g}^{-1}$, respectively. These results support the original assumption that $10 \%$ TiN is optimal, probably because this amount is needed to make a fairly continuous conductive network. The drop in capacity at $12.5 \%$ suggests that the TiN may then be starting to hinder lithium diffusion.

Fig. 7 also shows the variation in discharge capacity over 50 cycles of $\operatorname{LFP}\left(\mathrm{H}_{2} \mathrm{~N}_{2}\right)$-TiN $\left(\mathrm{NH}_{3}\right)$ samples with various TiN contents. The discharge capacity of $\operatorname{LFP}\left(\mathrm{H}_{2} \mathrm{~N}_{2}\right)-10 \mathrm{TiN}\left(\mathrm{NH}_{3}\right)$ decayed gradually with continuous cycling, retaining $123 \mathrm{~mA} \mathrm{~h} \mathrm{~g}^{-1}$ after 50 cycles, $82 \%$ of its initial capacity. The discharge capacity of the uncoated material faded to $68 \mathrm{~mA} \mathrm{~h} \mathrm{~g}{ }^{-1}$ over 50 cycles, a $37 \%$ capacity loss. It is well-established that the dissolution of Fe from $\mathrm{LiFePO}_{4}$ in $\mathrm{LiPF}_{6}$ electrolyte causes capacity fade. ${ }^{25}$ The improvement in cycle performance of $\operatorname{LFP}\left(\mathrm{H}_{2} \mathrm{~N}_{2}\right)-10 \mathrm{TiN}\left(\mathrm{NH}_{3}\right)$ relative to the uncoated material suggests that TiN modification on the surface of $\mathrm{LiFePO}_{4}$ is impeding erosion of the active material by the electrolyte. ${ }^{38,40}$ Fig. 6 shows that the coatings are still not continuous, so it is possible that further refinement of the coating method could deliver further improvements.

Coating $\mathrm{LiFePO}_{4}$ was intended to improve its performance by improving conductivity and surface stability, but TiN itself can undergo conversion reactions at low potential ${ }^{1}$ so we checked whether it was contributing to the capacity. Hence TiN- ${ }^{n} \mathrm{PrNH}_{2}\left(\mathrm{NH}_{3}\right)$ was treated as the active material to test this contribution. TiN electrodes were produced with acetylene black and a PVDF binder in exactly the same way as the TiNcoated $\mathrm{LiFePO}_{4}$ samples and assembled into lithium half-cells. The cyclic voltammetry over the potential range in which the TiN-LiFePO 4 cells are operated (Fig. S8†) shows small currents and very little change over 100 cycles of CV testing. This result is confirmed by the voltage profile vs. specific capacity during galvanostatic cycling (Fig. S8 $\dagger$ ). This experiment was carried out at a current rate of $170 \mathrm{~mA} \mathrm{~g}^{-1}$ of TiN, $10 \times$ that used in the $90 \%$ $\mathrm{LiFePO}_{4} / 10 \% \mathrm{TiN}$ electrodes, in order to keep the specific current relative to the TiN content the same. TiN- ${ }^{n} \operatorname{PrNH}_{2}\left(\mathrm{NH}_{3}\right)$ had a very low initial specific capacity of $0.46 \mathrm{~mA} \mathrm{~h}^{-1}$, and this remained lower than $0.5 \mathrm{~mA} \mathrm{~h} \mathrm{~g}^{-1}$ after 100 cycles. Hence the TiN was found to be electrochemically inert, confirming its action was mainly on the conductivity.

Fig. 8 shows the discharge capacity of selected samples at faster charge/discharge rates. The higher discharge capacities in the sample containing $10 \%$ TiN were maintained at these higher rates, with average capacities (over 5 cycles each) of 159, 149, 130, 109 and $89 \mathrm{~mA} \mathrm{~h} \mathrm{~g}^{-1}$ found at $0.1 \mathrm{C}, 0.2 \mathrm{C}, 0.5 \mathrm{C}, 1 \mathrm{C}$ and $2 \mathrm{C}$, respectively. The capacity plot $v$ s. inverse scan rate does not
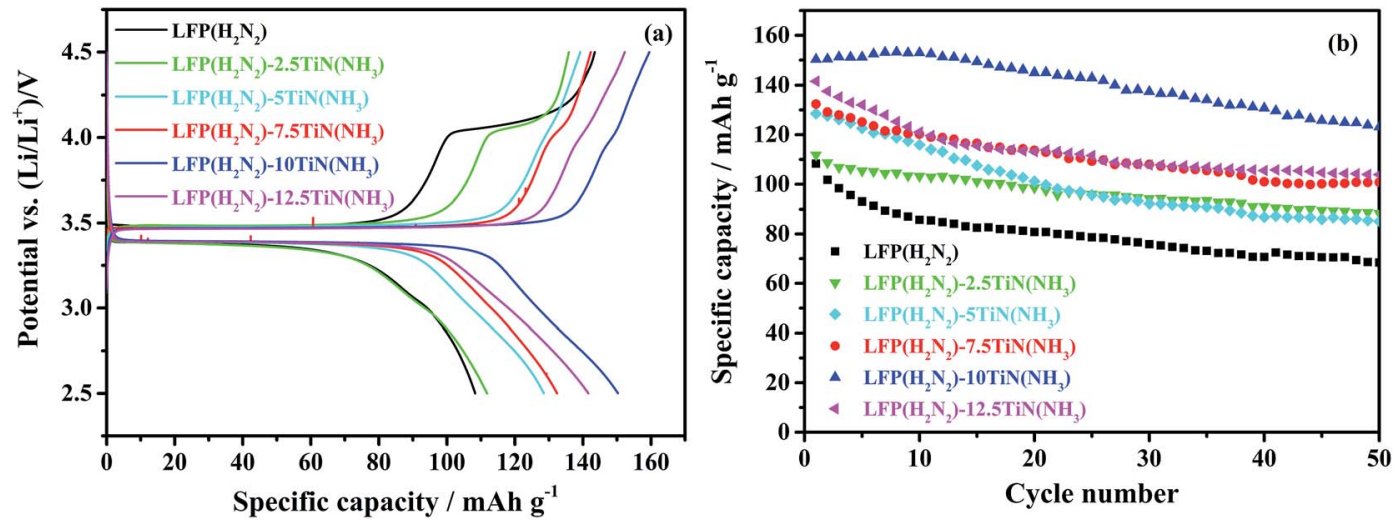

Fig. 7 The initial cycle of voltage profile against specific capacity (a) and specific capacity versus cycle number (b) of TiN-coated LiFePO $4 /$ Li half cells under galvanostatic cycling between 2.5 and $4.5 \mathrm{~V}$ at $0.1 \mathrm{C}$ (sample labels explained in Scheme 2, with the percentage of TiN in the composite written after the hyphen). 

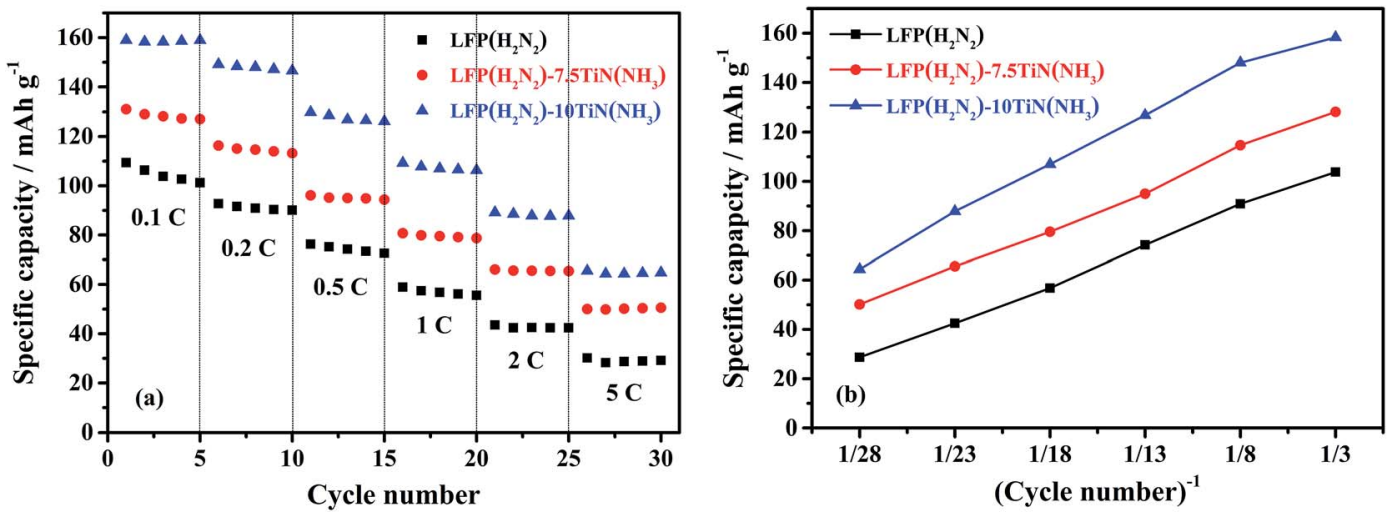

Fig. 8 The discharge specific capacity vs. cycle number (left) and plot of the average capacity in those groups vs. inverse cycle number (right) of uncoated and $\mathrm{TiN}_{\text {coated }} \mathrm{LiFePO}_{4}$ in Li half cells, cycled at various sequential rates from $0.1 \mathrm{C}$ to $5 \mathrm{C}$, between 2.5 and $4.5 \mathrm{~V}$ over 30 cycles (sample codes are described in Scheme 2, with the \% TiN noted after the hyphen).

plateau, showing that at still lower scan rates further capacity would be available. According to Huang, ${ }^{62}$ the capacity is most affected by the supply of electrons at high rates and hence this is the regime in which a low charge transfer resistance is most critical. $\mathrm{Hu}$ et al. found that carbon coating on porous $\mathrm{LiFePO}_{4}$ works well for lithium insertion at low current rates but does not at high current rates because of the insufficient electronically conducting network. ${ }^{63}$ Using nanometer-sized $\mathrm{RuO}_{2}$ as an oxidic interconnect, the kinetics and rate capability of the composite were significantly improved. Lu et al. reported a simple approach to enhance the electrical conductivity of olivine-structured $\mathrm{LiFePO}_{4}$ thin films by uniformly dispersing small fractions of highly conductive silver throughout the $\mathrm{LiFePO}_{4}$ film. ${ }^{64}$ The asobtained 200 nm-thick $\mathrm{LiFePO}_{4}-\mathrm{Ag}$ composite thin films provided a reversible discharge capacity of $46.3 \mu \mathrm{A} \mathrm{h} \mu \mathrm{m}^{-1} \mathrm{~cm}^{-2}$ $\left(>135 \mathrm{~mA} \mathrm{~h} \mathrm{~g}^{-1}\right.$ ) at a current density of $8 \mu \mathrm{A} \mathrm{cm}^{-2}(c a .0 .7 \mathrm{C})$. The observation that the capacity of $\operatorname{LFP}\left(\mathrm{H}_{2} \mathrm{~N}_{2}\right)-10 \mathrm{TiN}\left(\mathrm{NH}_{3}\right)$ drops quite significantly at higher rates suggests that the TiN coatings are not yet fully optimised to provide the fastest kinetics, but it is promising that our capacities at similar rates $\left(130 \mathrm{~mA} \mathrm{~h} \mathrm{~g}{ }^{-1}\right.$ at $0.5 \mathrm{C} ; 109 \mathrm{~mA} \mathrm{~h} \mathrm{~g}^{-1}$ at $1 \mathrm{C}$ ) are comparable.

Since the olivine $\mathrm{LiFePO}_{4}$ was reported by Goodenough and co-workers in $1997,{ }^{65}$ many researchers have tried to improve the performance of $\mathrm{LiFePO}_{4}$ by coating with carbon, metals or metal oxides to improve electronic conductivity. ${ }^{34,35,37,38,63,64}$ Well optimised carbon coatings allow $90 \%$ of its theoretical capacity to be used with acceptable rate capabilities. ${ }^{22,66}$ The novel propylamine cross-linking based sol-gel method to produce TiN coatings on $\mathrm{LiFePO}_{4}$ described herein already delivers a significant fraction of the electrochemical performance that is currently achieved with carbon after several years of intense activity. It appears to both increase the electronic conductivity of the $\mathrm{LiFePO}_{4}$ to deliver higher capacities than the uncoated material, and to reduce corrosion due to iron dissolution and hence retain a larger fraction of the initial capacity during continuous cycling. We note that our sol-gel process transfers close to $100 \%$ (mechanical losses only) of the titanium precursor to the $\mathrm{TiN} / \mathrm{LiFePO}_{4}$ composite so has a lower precursor cost than more wasteful CVD or ALD approaches.
However, TiN will always be a more costly coating material than carbon and would not be expected to replace it in standard applications. It may have advantages for battery materials run under non-standard conditions where carbon coatings may be unstable, e.g. with high voltage electrode materials or for cells that need to be able to operate at high temperature. Now that the system has been benchmarked with $\mathrm{LiFePO}_{4}$, future work will examine these areas.

\section{Conclusions}

Sol-gel approaches to the coating of battery materials with titanium nitride have been explored. A propylamine crosslinking method gave higher electronic conductivity materials than ammonia cross-linking, and hence was used to produce the coatings. Firing in ammonia also resulted in lower carbon contents, so $\mathrm{LiFePO}_{4}$ was examined after firing in ammonia and found to be comparable with the material fired more conventionally in a dilute hydrogen mix. TiN-coated $\mathrm{LiFePO}_{4}$ performed well as an electrode material in lithium half cells, with capacities, cycling performance and rate capabilities in the best cases that were competitive with other coating materials. $\mathrm{LiFePO}_{4}$ modified with $10 \mathrm{wt} \%$ TiN from the propylamine crosslinking method and fired in ammonia exhibits a maximum discharge capacity of $159 \mathrm{~mA} \mathrm{~h} \mathrm{~g}^{-1}$, that is $93 \%$ of the theoretical capacity $\left(170 \mathrm{~mA} \mathrm{~h} \mathrm{~g}^{-1}\right)$, at the rate of $0.1 \mathrm{C}$. There is room to further improve the performance of these coating materials, and they may provide good options for batteries used in nonstandard conditions.

\section{Acknowledgements}

MZ thanks the China Scholarship Council (CSC) and the University of Southampton for support. NGA thanks the EPSRC for an early career fellowship (EP/N024303/1).

\section{Notes and references}

1 M.-S. Balogun, W. Qiu, W. Wang, P. Fang, X. Lu and Y. Tong, J. Mater. Chem. A, 2015, 3, 1364-1387. 
2 I.-S. Kim, P. N. Kumta and G. E. Blomgren, in Materials for Electrochemical Energy Conversion and Storage, The American Ceramic Society, 2006, pp. 249-258, DOI: 10.1002/9781118370858.ch25.

3 S. Dong, X. Chen, L. Gu, X. Zhou, L. Li, Z. Liu, P. Han, H. Xu, J. Yao, H. Wang, X. Zhang, C. Shang, G. Cui and L. Chen, Energy Environ. Sci., 2011, 4, 3502-3508.

4 I.-S. Kim, P. N. Kumta and G. E. Blomgren, Electrochem. Solid-State Lett., 2000, 3, 493-496.

5 M. Q. Snyder, S. A. Trebukhova, B. Ravdel, M. C. Wheeler, J. DiCarlo, C. P. Tripp and W. J. DeSisto, J. Power Sources, 2007, 165, 379-385.

6 J. H. Bang and K. S. Suslick, Adv. Mater., 2009, 21, 3186-3190.

7 E. L. Memarzadeh, W. P. Kalisvaart, A. Kohandehghan, B. Zahiri, C. M. B. Holt and D. Mitlin, J. Mater. Chem., 2012, 22, 6655-6668.

8 A. Salamat, A. L. Hector, P. Kroll and P. F. McMillan, Coord. Chem. Rev., 2013, 257, 2063-2072.

9 S. Dong, X. Chen, X. Zhang and G. Cui, Coord. Chem. Rev., 2013, 257, 1946-1956.

10 A. Kafizas, C. J. Carmalt and I. P. Parkin, Coord. Chem. Rev., 2013, 257, 2073-2119.

11 E. G. Gillan and R. B. Kaner, J. Mater. Chem., 2001, 11, 19511956.

12 B. Mazumder, P. Chirico and A. L. Hector, Inorg. Chem., 2008, 47, 9684-9690.

13 A. W. Jackson and A. L. Hector, J. Mater. Chem., 2007, 17, 1016-1022.

14 F. Cheng, S. M. Kelly, S. Clark, N. A. Young, S. J. Archibald, J. S. Bradley and F. Lefebvre, Chem. Mater., 2005, 17, 55945602.

15 A. L. Hector, Chem. Soc. Rev., 2007, 36, 1745-1753.

16 A. L. Hector, Coord. Chem. Rev., 2016, 323, 120-137.

17 D. Choi and P. N. Kumta, J. Electrochem. Soc., 2006, 153, A2298-A2303.

18 A. W. Jackson, O. Shebanova, A. L. Hector and P. F. McMillan, J. Solid State Chem., 2006, 179, 1383-1393.

19 C. F. Mallinson, B. M. Gray, A. L. Hector, M. A. McLachlan and J. R. Owen, Inorg. Chem., 2013, 52, 9994-9999.

20 B. M. Gray, S. Hassan, A. L. Hector, A. Kalaji and B. Mazumder, Chem. Mater., 2009, 21, 4210-4215.

21 R. Dominko, M. Bele, J.-M. Goupil, M. Gaberscek, D. Hanzel, I. Arcon and J. Jamnik, Chem. Mater., 2007, 19, 2960-2969.

22 Y. Wang, Y. Wang, E. Hosono, K. Wang and H. Zhou, Angew. Chem., Int. Ed., 2008, 47, 7461-7465.

23 F. Yu, L. Zhang, L. Lai, M. Zhu, Y. Guo, L. Xia, P. Qi, G. Wang and B. Dai, Electrochim. Acta, 2015, 151, 240-248.

24 Q. Fan, L. Lei, Y. Chen and Y. Sun, J. Power Sources, 2013, 244, 702-706.

25 H.-H. Chang, H.-C. Wu and N.-L. Wu, Electrochem. Commun., 2008, 10, 1823-1826.

26 S. Deng, H. Wang, H. Liu, J. Liu and H. Yan, Nano-Micro Lett., 2014, 6, 209-226.

27 C. Gong, Z. Xue, S. Wen, Y. Ye and X. Xie, J. Power Sources, 2016, 318, 93-112.

28 M. R. Roberts, G. Vitins, G. Denuault and J. R. Owen, J. Electrochem. Soc., 2010, 157, A381-A386.
29 M. R. Roberts, G. Vitins and J. R. Owen, J. Power Sources, 2008, 179, 754-762.

30 I. D. Johnson, E. Blagovidova, P. A. Dingwall, D. J. L. Brett, P. R. Shearing and J. A. Darr, J. Power Sources, 2016, 326, 476-481.

31 H. Yuan, X. Wang, Q. Wu, H. Shu and X. Yang, J. Alloys Compd., 2016, 675, 187-194.

32 Y. Zhang, L. Wu, J. Zhao and W. Yu, J. Electroanal. Chem., 2014, 719, 1-6.

33 K. Vediappan, A. Guerfi, V. Gariépy, G. P. Demopoulos, P. Hovington, J. Trottier, A. Mauger, C. M. Julien and K. Zaghib, J. Power Sources, 2014, 266, 99-106.

34 P. P. Prosini, D. Zane and M. Pasquali, Electrochim. Acta, 2001, 46, 3517-3523.

35 S. W. Oh, S. T. Myung, S. M. Oh, K. H. Oh, K. Amine, B. Scrosati and Y. K. Sun, Adv. Mater., 2010, 22, 4842-4845.

36 Y. Liu, M. Zhang, Y. Li, Y. Hu, M. Zhu, H. Jin and W. Li, Electrochim. Acta, 2015, 176, 689-693.

37 Y. Jin, C. Yang, X. Rui, T. Cheng and C. Chen, J. Power Sources, 2011, 196, 5623-5630.

38 Y. Lin, Y. Lin, T. Zhou, G. Zhao, Y. Huang and Z. Huang, J. Power Sources, 2013, 226, 20-26.

39 W.-J. Zhang, J. Power Sources, 2011, 196, 2962-2970.

40 J. Cao, Y. Qu and R. Guo, Electrochim. Acta, 2012, 67, 152158.

41 J. Chen, Materials, 2013, 6, 156-183.

42 J. Wang and X. Sun, Energy Environ. Sci., 2012, 5, 5163-5185.

43 T. Yi, X. Li, H. Liu, J. Shu, Y. Zhu and R. Zhu, Ionics, 2012, 18, 529-539.

44 X. Lu, G. Wang, T. Zhai, M. Yu, S. Xie, Y. Ling, C. Liang, Y. Tong and Y. Li, Nano Lett., 2012, 12, 5376-5381.

45 Y. Xu and J. Mao, J. Mater. Sci., 2016, 51, 10026-10034.

46 A. Larson, R. Von Dreele, L. Finger, M. Kroeker and B. Toby, J. Appl. Crystallogr., 2001, 34, 210-213.

47 E. Bailey, N. M. Ray, A. L. Hector, P. Crozier, W. T. Petuskey and P. F. McMillan, Materials, 2011, 4, 1747-1762.

48 L.-X. Yuan, Z.-H. Wang, W.-X. Zhang, X.-L. Hu, J.-T. Chen, Y.-H. Huang and J. B. Goodenough, Energy Environ. Sci., 2011, 4, 269-284.

49 Y. Zhang, Q.-Y. Huo, P.-P. Du, L.-Z. Wang, A.-Q. Zhang, Y.-H. Song, Y. Lv and G.-Y. Li, Synth. Met., 2012, 162, 13151326.

50 W. Hofmann and A. Schrader, Arch. Eisenhuettenwes., 1936, 10, 65-66.

51 Y. Zhang, Q. Huo, P. Du, L. Wang, A. Zhang, Y. Song, Y. Lv and G. Li, Synth. Met., 2012, 162, 1315-1326.

52 A. D. Spong, G. Vitins and J. R. Owen, J. Electrochem. Soc., 2005, 152, A2376-A2382.

53 Y. Gu, C. Zeng, H. Wu, H. Cui, X. Huang, X. Liu, C. Wang, Z. Yang and H. Liu, Mater. Lett., 2007, 61, 4700-4702.

54 K. Wang, R. Cai, T. Yuan, X. Yu, R. Ran and Z. Shao, Electrochim. Acta, 2009, 54, 2861-2868.

55 M. Konarova and I. Taniguchi, J. Power Sources, 2009, 194, 1029-1035.

56 M. Bianchini, J.-B. Leriche, J.-L. Laborier, L. Gendrin, E. Suard, L. Croguennec and C. Masquelier, J. Electrochem. Soc., 2013, 160, A2176-A2183. 
57 Y. Wang, P. He and H. Zhou, Energy Environ. Sci., 2011, 4, 805-817.

58 Y. Cui, X. Zhao and R. Guo, Electrochim. Acta, 2010, 55, 922926.

59 Y. Cui, X. Zhao and R. Guo, Mater. Res. Bull., 2010, 45, 844849.

60 H. Liu, G. X. Wang, D. Wexler, J. Z. Wang and H. K. Liu, Electrochem. Commun., 2008, 10, 165-169.

61 C.-Z. Lu, G. T.-K. Fey and H.-M. Kao, J. Power Sources, 2009, 189, 155-162.
62 X. Huang, X. Li, H. Wang, Z. Pan, M. Qu and Z. Yu, Electrochim. Acta, 2010, 55, 7362-7366.

63 Y. S. Hu, Y. G. Guo, R. Dominko, M. Gaberscek, J. Jamnik and J. Maier, Adv. Mater., 2007, 19, 1963-1966.

64 Z. G. Lu, H. Cheng, M. F. Lo and C. Y. Chung, Adv. Funct. Mater., 2007, 17, 3885-3896.

65 A. K. Padhi, K. Nanjundaswamy and J. Goodenough, J. Electrochem. Soc., 1997, 144, 1188-1194.

66 Y. J. Lee, H. Yi, W.-J. Kim, K. Kang, D. S. Yun, M. S. Strano, G. Ceder and A. M. Belcher, Science, 2009, 324, 1051-1055. 